\title{
Az apa szerepe a kisgyermek életében
}

\author{
Benedek Szidónia Anna - Dorner László \\ Eszterházy Károly Föiskola, Pszichológia Tanszék
}

\begin{abstract}
Háttér és célok: Jelen tanulmány a történeti áttekintést követően egy friss empirikus kutatás segítségével kísérel meg választ adni egy évezredek óta aktuális, ugyanakkor napjainkban kiemelten fontossá váló kérdésre: Mi az apa szerepe napjainkban? Milyen szerepet tölt be jelenléte a kisgyermek életében? Ezen kérdések mellett a hagyományos nemi szerepelvárások jellegzetességeinek vizsgálata is indokolt: Mit gondolnak a bölcsődei ellátást igénybe vevő édesapák a saját családi és gyermeknevelési feladatrendszerükröl, milyen tevékenységeket tartanak inkább az édesanya, és miket inkább az édesapa feladatának? Milyen játéktevékenységeket preferálnak kisgyermekeikkel, és fontosnak tartják-e, hogy gyermekük hasonló tevékenységek iránt mutasson érdeklődést, mint ők?

Módszer és minta: A vizsgálatba 101 édesapát vontunk be, akik egy általunk kidolgozott önkitöltős kérdőívet töltöttek ki. A minta 80\%-ának gyermeke bölcsődei ellátást vesz igénybe.

Eredmények: A jelen mintában szereplö édesapák a hagyományos nemi szerepelvárásokat továbbra is fontosnak tartják, így az anyagi biztonság megteremtését elsődleges feladatuknak tekintik, míg a nők tekintetében a gyermeknevelést és -gondozást tartják elsődlegesnek, ugyanakkor saját feladataik között is az elsők között említik a gyermekgondozást, így feltételezhetjük, hogy a "modern apák” korában a szeretetteljesebb, gondoskodóbb apai szerep is egyre jobban integrálódik szereprepertoárjukba. Láthatjuk továbbá azt is, hogy a fiúgyermeket nevelő apák számára fontosabb a gyermekük hasonló érdeklödési köre, illetve, hogy az apák továbbra is preferálják a hevesebb, „férfiasabb” játéktevékenységeket gyermekeikkel, mint a birkózás és az építő játékok.
\end{abstract}

Kulcsszavak: apa szerepe, kisgyermek, játéktevékenységek, szülői szerepmegosztás, nemi különbségek

\section{Szakirodalmi áttekintés}

Az apa jelenléte már az őskortól kezdve fontos szerepet játszott a gyermek életében, annak csupán jellege változott, és változik folyamatosan. Trendek jönnek-mennek, de a férfira, mint szülöre és nemi szerepmodellre mindig szüksége lesz a gyermeknek (Pukánszky, 2001).

Az őskorban a túléléshez szükséges eszközök elkészítésének titka apáról fiúra szállt, így a tanulás módszere a megfigyelés és utánzás kombinációjára korlátozódott (Pukánszky, 2001). Az ókorból kevés forrás áll a rendelkezésünkre, azonban az így is elmondható, hogy társadalmi rétegtöl függetlenül a gyermek a családban, annak müködésében már ekkor is fontos szerepet töltött be. Kultúrától függetlenül jellemző volt, hogy a gyermek jogi képviseletét teljhatalmúlag az apa gyakorolta, ez a társadalom militarizáltságára is utalt (Contenau,1954; Gurney, 1954 idézi: French,1998). Újabb érdekes szempontot vet fel az ókori Egyiptom forrásanyaga, ahol azt olvashatjuk, hogy már ekkoriban felismerték a gyermekek játékigényeit és a játéktevékenység fontosságát (White, 1963, idézi: French, 1998). Ezen felül, tiltották a gyermekgyilkosságot, amely sok egyéb ókori kultúrában megengedettnek számított (Pukánszky, 2001). Ezzel szemben az ókori Rómában az apa akkor is rendelkezhetett gyermeke életéről, ha az már felnőtt, vagy 
életben hagyásáról korábban döntöttek. Ez a szokás az i.sz. II. századra, először a bántalmazások számának csökkenésével, majd a felnőtt fiát meggyilkoló apa számüzésével kikopott a társadalomból (French, 1998). Olyannyira, hogy a középkor társadalma, már csak 5-6 éves koráig tekintett valakit gyermeknek (Ariés, 1987). A felvilágosodás idején Rousseau úgy ír az apáról, hogy az ő kötelessége a családfenntartás és a gyermeknevelés, kihangsúlyozva, hogy a gyermeknek kell a középpontban állnia, a korfelfogás szerinti múveltséggel szemben (Pukánszky, 2001). A XX. századra a gyermek iránti figyelem fokozatos növekedést mutatott, miközben leggyakrabban a megengedő és a szigorú apai nevelői stílussal találkozunk ekkoriban (Tomka, 2000).

Ahogy az előbbiekben felvázoltuk, a gyermekkép és az apaszerep is egyaránt jelentős változásokon esett át a történelem folyamán. Napjainkban az apa-gyerek kapcsolat tekintetében elsősorban az apai személyiséget és a gyermekhez való hozzáállást vizsgáljuk. Ezek alapján a szülő lehet korlátozó, aki merev és következetes szabályokat alkot, melyhez szigorúan ragaszkodik; engedékeny, aki szintén alkot szabályokat, de emellett engedi a gyermeket érvényesülni. Ezen felül érzelmi viszonyulása lehet meleg, aki a gyermek érdekeit helyezi előtérbe, pozitív megerősítéssel és cselekedeteinek indoklásával fordul a gyermek felé. Ezzel ellentétben a hideg nevelői stílusú szülő, gyermekét nem erősíti, bátorítja, érzelmi melegséget nem biztosít a gyermek számára. Ezek összessége és variáció alapján négyféle lehetséges nevelési stílust különíthetünk el: Meleg-engedékeny, hideg-engedékeny, meleg-korlátozó és hideg-korlátozó (Ranschburg, 2009). Ezen felül természetesen kiemelhetjük, hogy a biztonságos kötődés kialakulása apa és gyermeke között ugyanolyan fontossággal bír, mint az anya és gyermeke között, bár a jellege eltérő. Ainsworth 1978-ban alkotta meg széles körben használt teszthelyzetét, az Idegen Helyzet Tesztet, mely során a gyermek és az egyik szülő egy számukra ismeretlen szobába lépnek be. A teszt ideje alatt a szülö kétszer magára hagyja gyermekét, majd visszamegy hozzá, eközben megjelenik egy idegen, aki a gyermek reakciójára reagálva lehet aktív vagy passzív, de minden esetben barátságos. Ezen bonyolult kísérleti elrendezés alapján megkülönböztetünk biztonságosan kötődő, bizonytalan-elkerülő, ambivalens, illetve dezorganizáltan kötődő gyermeket (Vajda, 1999). Megfigyelték továbbá, hogy az Idegen Helyzet Teszt során a gyermekek apák és anyák felé mutatott kötődése nem tér el egymástól, ahogyan a szülői nevelői attitüdök sem specifikusak egyik szülő irányában sem (Ranschburg, 2009). Azokat az apákat, akik már gyakrabban és aktívabban vállalnak részt gyermekeik nevelésében, szívesebben mutatják ki gyengéd érzelmeiket a gyermekeik felé, „Modern apák”-nak nevezzük. Korábban a férfiakkal szemben fennálló társadalmi elvárások sokszor akadályozták az apákat szeretetük szavakba öntésében (Simóm, Sánchez és Elizalde, 2005). Kutatásában már Robin Sullivan (2003) sem talált egyértelmü határvonalat anya- és apaszerep között, mivel ezek összemosódtak, valamint a gyermek egészséges fejlődéséhez mindkét nemű szülőjére szüksége van a gyermeknek. A várandósság ideje alatt a férfiak sokszor nem tudják kezelni az új helyzettel járó új érzéseket (Ranschburg, 2009). Ezek az érzések, félelmek, általában abból erednek, hogy a férfiak háttérbe szorítva érzik magukat (Spock és Parker, 2010). Fontos, hogy ha az apa nincs teljesen tisztában saját érzéseivel, akkor minél aktívabban részt vegyen a szülés előtti időkben, például a vizsgálatokkor, vagy a gyermekfelszerelés vásárlás alkalmával (Sears, 2006). Mivel a férfiak nem észlelik a terhesség alatt a gyermek jelenlétét olyan intenzíven, mint a nők, ezért náluk nehezebben és lassabban fogalmazódik meg a tudat, hogy hamarosan apává válnak. Van, akinél már az első ultrahangos vizsgálat alkalmával, van, akinél az anya hasának érintésekor, amikor a magzat érzékelhetően mozgolódik, rugdos, de van, akinél csak a szülést követően jön el szülőségének felismerése (Ranschburg, 2009). Habár az apák is képesek az anyákhoz hasonló szerepet betölteni a gyermek életében, a leggyakoribb 
példa mégis az, hogy amíg a gyermek kicsi, az apák nem hasonlítanak viselkedésükben, szerepükben az anyákra (Bowlby, 2009). Mivel a gyermek élete első hónapjaiban leggyakrabban szoptatás közben alszik el, az apák olykor tanácstalanok, ha rájuk hárul az altatás feladata. llyenkor sokszor erős a kísértés, hogy visszaadják a babát az anyának, pedig a csecsemők előszeretettel elalszanak apjuk mellkasán, hisz a meleg bőr, a szívverés hangja és a légzés ritmusa könnyedén álomba ringatja őket. Máskor azonban elegendő ehhez az apai hang mély duruzsolása (Sears, 2006). Minden gyermeknek szüksége van rá, hogy felnőttek - leginkább saját szüleik - közelében lehessenek. Egyrészt a gyermek így érzi, hogy szeretik, szívesen időznek társaságában, és élvezheti a megnyilvánuló gyengédséget. Másrészt ez azért is fontos, mert a gyermekek elsősorban utánzással sajátítanak el dolgokat, és tanulják el a nemi- és társas szerepeket (Spock és Parker, 2010). Fiúgyermekek esetében az apák sokszor akaratlanul is elkövetik az a hibát, hogy a saját képükre igyekszenek formálni a gyermeket, és olyan tevékenységeket végeznek velük, amikben ők lelik örömüket. Ilyenkor sokszor irreleváns elvárásokat támasztanak fiaikkal szemben. Ha dicséret és bátorítás helyett az apa folyton csak kritizálja és bírálja gyermekét, a fia egy idő után már nem leli örömét a játékban, sőt szélsőséges esetben az apával töltött időben sem (Spock és Parker, 2010). A kislányok életében is nélkülözhetetlen szerepe van az apának, hiszen bár példát csak korlátozottan vesz apjáról, de önbizalma nagy részét apjával való kapcsolatából meríti. Fontos éreznie egy lánynak, hogy apját érdeklik lányos tevékenységei, játékai is, véleménye, céljai, valamint érzi, hogy apja szívesen lenne vele, hisz ezek a tapasztalatok később meghatározzák életét a párválasztás és a férfiakkal való kapcsolata terén is (Spock és Parker, 2010). Megfigyelések szerint az apák leginkább fizikai játékokat játszanak gyermekeikkel és ez hatványozottan igaz, ha a gyermek fiú és fizikai állapota ezt lehetővé teszi. Bár a három év körüli fiúk dédelgetésért és gondoskodásért továbbra is anyjukhoz fordulnak, de a játszótársat már apjukban találják meg, hiába jelenik meg a legtöbb családban az apa a fegyelmező és tanító szerepében (Ranschburg, 2003). Ma Magyarországon körülbelül 25000 a válások száma évente, ebböl 60-62\% az aránya a kisgyermekkel rendelkező házas feleknek. Az esetek 88\%-ban a gyermeket az anya neveli tovább, és mindössze $12 \%$-ban rendelkezik az apa a gyermek(ek) felügyeleti jogával. Ez egyrészt a társadalmi hagyományoknak köszönhető, mely szerint a házas felek közül az anya az egyetlen, aki érdemben ért a gyermekneveléshez, pedig ez sokszor nem felel meg a valóságnak. Az elvált, gyermeküktől külön élő apák között többségben vannak azok, akik maguk is elvált szülök gyerekei (Vukovics, 2006). Végül érdemes megemlítenünk az utóbbi évtized talán legnagyobb hatású szerzőjét, Jorgen Lorentzent, aki Norvégiában - ahol az egalitariánus nézetek az utóbbi évtizedekben erősen teret nyertek, és az apák számára például gyermekgondozási szabadságot vezettek be - új színt vitt az apaság szerepének kutatásába. Lorentzen (2012) ugyanis kiemeli például, hogy egy ország esetében egységes apaszerepről semmiképpen nem beszélhetünk, mivel jelentős különbséget mutat például a polgári és a munkáscsaládok gyermeknevelési gyakorlata, valamint az etnikai viszonyok szerepe is fontos, gondoljunk például a bevándorló családok eltérő gyakorlatára a többségi társadalomhoz képest. Kiemeli továbbá abbéli meggyőződését, hogy ha egy társadalomban megváltoznak az apaszereppel kapcsolatos gondolatok, vélekedések, az az ezzel összefüggő gyakorlati gyermeknevelési magatartásra is hatást gyakorol. Két kulcsfogalmat vezet be, az apa a családért-apa jelentésben a család eltartója szerepét tölti be, ez mindvégig domináns elképzelés maradt, emellé azonban társult az 1970-es évektől a családban-apa koncepció, mely arra vonatkozik, amikor az apa a gyerekekröl gondoskodó személyként jelen is van, részt vesz a család életében. Ez a családdal való intim, bensőséges kapcsolatot is előfeltételezi, amely korábban szinte kizárólag az anyák felségterülete volt. 


\section{Kutatás}

\section{A kutatás célja, kérdései, hipotézisei}

A kutatás során arra kerestük a választ, hogy a férfiak mennyire gondolkodnak eltérően az apaság fogalmáról, illetve, hogy a felvett szerepek egyénenként mennyire térnek el egymástól. A hipotézisek - melyek egyrészt a szakirodalmon, másrészt saját feltevéseinken alapulnak - és a kérdőív összeállítását egy beszélgetés-sorozat előzte meg gyakorló apákkal, az ő narratíváik elemzése alapján készítettük el a fővizsgálatban használt kérdéssort. Ezek alapján négy hipotézis fogalmazódott meg bennünk. Az első hipotézis szerint a férfiak többsége úgy gondolja, hogy a gyermeknevelés és a gyermekgondozás elsődlegesen az édesanyák feladata. Második hipotézisünk szerint a férfiak többsége a gyermeknevelést és -gondozást az édesanyák feladatának tartják, saját feladatuknak az anyagi biztonság megteremtését tekintik. Az apa-gyermek kapcsolatot harmadik hipotézisünkkel vizsgáltuk, mely szerint az édesapák gyakrabban játszanak olyan fizikai játékokat gyermekeikkel, mint a csiklandozás, feldobálás és birkózás, mint egyéb szellemi vagy szerepjátékokkal. Végül a negyedik hipotézisünk az apa-gyermek kötődést vizsgálja, arra a kérdésre keresve a választ, hogy ha az apa jelen van gyermeke születésénél, akkor a gyermek nagyobb valószínűséggel mutatja- e a biztonságos kötődés jeleit apja felé.

\section{A kutatási módszer}

Az édesapák számára összeállított kérdőív, mely föleg rangsorolási feladatokat tartalmaz, azt vizsgálja, hogy a férfiak miként gondolkodnak az apai és anyai feladatokról, milyen játékokat milyen gyakorisággal játszanak gyermekükkel, fontos e számukra, hogy gyermekük hozzájuk hasonló érdeklődési körrel rendelkezzen, illetve, hogy befolyásolja-e az apa-gyermek kötődést, ha az apa jelen van a szülőszobában. Ez utóbbit külön kérdéssel vizsgáltuk („Jelen volt-e a szülőszobán?”), a kötődés dimenzióit pedig az Ainsworth-féle Idegen Helyzet Tesztben tapasztalt kötődési mintázatok önértékelésen alapuló megjelenési gyakorisága alapján vizsgáltuk (Lásd 1. melléklet, 14-15. kérdés). Ennek hátterében az áll, hogy egyértelmüen látható, hogy a szülői gondozói viselkedés a kötődés fontos aspektusának tekinthető.

\section{Vizsgálat menete}

Az kérdőívek felvételére 2014. február 24. és március 9. között került sor, egri, szolnoki, tiszafüredi, egyeki és budapesti édesapák önkéntes és anonim részvételével, személyes megkeresés után. A kitöltők egy részét hólabda mintavétel segítségével értük el, másik részét pedig ezen települések bölcsődei gondozónőinek segítségével, akik segítettek a papír alapú kérdőívek apákhoz való eljuttatásában. A részvételhez a gyermekek életkorát 5 évben maximalizáltuk, mivel ebben az életkorban legintenzívebb a személyiségfejlődésük és a felnőttekhez való kapcsolatuk feltehetően a legőszintébb. A közel 110 kiosztott kérdőívböl, 101 darab érkezett vissza kitöltve, melyeket az SPSS 20.0 program segítségével elemeztünk.

\section{Eredmények}

A kitöltő férfiak életkora 26 évtöl 52 évig terjed, átlagban 35 év. Végzettség szempontjából a férfiak 48,5 \%-a rendelkezik főiskolai/egyetemi diplomával, a maradék 51,5\% 
pedig nagyjából fele-fele arányban oszlik meg a gimnáziumi érettségivel rendelkezők $(24,8 \%)$ és a szakmunkás/szakiskola/szakközépiskola/technikum végzettségűek (26,7 \%) között. A gyermekek 60,4\%-a lány, míg 39,6 \%-a fiú. A gyermekek 80,2 \%-a bölcsődébe jár. Bár 5 és 60 hónapos kor között szinte minden életkor megtalálható volt, a magas bölcsődei jelenlét miatt a legtöbb gyermek a harmadik életévében, (25 és 36 hónapos kor) járt. Amikor a kitöltők az anyák és apák feladatait rangsorolták, meglepő ellentétekkel találkoztunk. A rendelkezésre álló 6 fogalmat mint a Gyermeknevelés (vigasztalás, ringatás, meseolvasás stb.); Gyermekgondozás (etetés, fürdetés, pelenkázás stb.); Házastárssal töltött idő; Háztartásvezetés (fözés, mosás, takarítás stb.), Háztartás körüli teendők (fünyírás, karbantartás, villanykörtecsere stb.), Családfenntartás és az Anyagi biztonság megteremtése, olyan módon kellett sorrendbe rakni, hogy a legnagyobb prioritású feladat kerüljön az első, míg a legkevésbé fontosnak vélt feladat az utolsó helyre az adott nemü szülőnél. A fogalmakat saját ötleteink és az előzetes beszélgetésekben leggyakrabban előforduló tevékenységek alapján állítottuk össze, igyekezve lefedni a tradicionálisan férfi és női szerepeknek megfelelő tevékenységeket. Ezen kívül mind a két feladatban ugyanazok voltak a fogalmak, eltérés csupán a sorrendben volt. Az anyák feladatainak megítélésében egyértelmü mintázat mutatkozik. Láthatóvá vált, hogy az apák szerint a nő elsődleges feladatai közé tartozik a gyermek ellátása, de a többi területen is a társadalmilag tradicionálisan elfogadott/elvárt szerepeknek megfelelő rangsor alakult ki, mely szerint a nő elsődlegesen a gyermek gondozásával-nevelésével kapcsolatos feladatrendszerekkel asszociálódik az apák reprezentációjában, a partner/házastárs szerep kevésbé jelenik meg.

\begin{tabular}{|c|c|c|c|c|c|c|}
\hline & $\begin{array}{c}\text { Anyagi } \\
\text { biztonság } \\
\text { megteremtése }\end{array}$ & $\begin{array}{l}\text { Háztartás- } \\
\text { vezetés }\end{array}$ & $\begin{array}{l}\text { Gyermek- } \\
\text { nevelés }\end{array}$ & $\begin{array}{l}\text { Házastárssal } \\
\text { töltött idő }\end{array}$ & $\begin{array}{l}\text { Gyermek- } \\
\text { gondozás }\end{array}$ & $\begin{array}{l}\text { Háztartás } \\
\text { körüli teendök }\end{array}$ \\
\hline 1. & $3 \%$ & $10,9 \%$ & $60,4 \%$ & $6,9 \%$ & $33,7 \%$ & \multirow{3}{*}{$0 \%$} \\
\hline 2. & $5,9 \%$ & $17,8 \%$ & $27,7 \%$ & $11,9 \%$ & $48,5 \%$ & \\
\hline 3. & $8,9 \%$ & $26,7 \%$ & $11,9 \%$ & $35,6 \%$ & $15,8 \%$ & \\
\hline 4. & $5 \%$ & $34,7 \%$ & \multirow{3}{*}{$0 \%$} & $37,6 \%$ & $2 \%$ & $9 \%$ \\
\hline 5. & $47,5 \%$ & $8,9 \%$ & & $7,9 \%$ & \multirow{2}{*}{$0 \%$} & $24,8 \%$ \\
\hline 6. & $29,7 \%$ & $1 \%$ & & $0 \%$ & & $64,4 \%$ \\
\hline
\end{tabular}

1. táblázat: A különböző szerepek százalékos megjelenése az ANYA feladatainak megítélésében

Az 1. táblázatból látszik, hogy a kitöltő édesapák több mint $80 \%$-a a Gyermeknevelést és a Gyermekgondozást egyaránt a táblázat első két helyére pozícionálta. $A$ Házastárssal töltött idő és a Háztartásvezetés közel azonos értékkel szerepel, mivel ez a két tevékenység a harmadik és negyedik helyen szerepelt a leggyakrabban az édesapák besorolása alapján. Az Anyagi biztonság megteremtését a kitöltők 77,2 \%-a sorolta az utolsó két hely egyikére, tehát nem tartják kiemelten fontos anyai feladatnak. A Háztartás körüli teendők a minta 64,4\%-ának véleménye szerint a legkevésbé fontos anyai teendő, azonban érdemes azt is megfigyelni, hogy senki nem sorolta az első három helyre a fogalmat.

Ezzel szemben a férfiak saját, domináns szerepelképzeléseik tekintetében az anyákétól nagymértékben különböző mintázatot mutatnak, ami a nemi szerepelvárások tekintetében felállított sorrendben hangsúlyosan megjelenik. Náluk a család anyagi biztonságának megteremtése kiugróan magas, 81,2 \%-ban jelent meg első helyre sorolt feladatként. A másik ilyen szembeötlő terület a háztartásvezetés, mely a kitöltők 
74,3 \%-ánál jelent meg utolsó helyen. Bár manapság az apák már nagyobb mértékben részt vesznek gyermekeik életében (Sullivan, 2003), kutatásunk szerint mégsem gondolják úgy, hogy a gyermekeik gondozása és nevelése ugyanannyira lenne az ő feladatuk is, mint az anyáké, ezzel szintén a hagyományos szerepelvárásoknak a társadalmunkban hangsúlyos voltát alátámasztva.

\begin{tabular}{|c|c|c|c|c|c|c|}
\cline { 2 - 6 } & $\begin{array}{c}\text { Anyagi } \\
\text { biztonság } \\
\text { megteremtése }\end{array}$ & $\begin{array}{c}\text { Háztartás- } \\
\text { vezetés }\end{array}$ & $\begin{array}{c}\text { Gyermek } \\
\text { nevelés }\end{array}$ & $\begin{array}{c}\text { Házastárssal } \\
\text { töltött idő }\end{array}$ & $\begin{array}{c}\text { Gyermek- } \\
\text { gondozás }\end{array}$ & $\begin{array}{c}\text { Háztartás } \\
\text { körüli teendők }\end{array}$ \\
\hline 1. & $\mathbf{8 1 , 2} \%$ & $0 \%$ & $11,9 \%$ & $12,9 \%$ & $5 \%$ & $3 \%$ \\
\hline 2. & $9,9 \%$ & $2 \%$ & $26,7 \%$ & $15,8 \%$ & $\mathbf{3 5 , 6} \%$ & $17,8 \%$ \\
\hline 3. & $7,9 \%$ & $4 \%$ & $\mathbf{4 4 , 6} \%$ & $22,8 \%$ & $12,9 \%$ & $10,9 \%$ \\
\hline 4. & $1 \%$ & $5 \%$ & $3 \%$ & $31,7 \%$ & $26,7 \%$ & $28,7 \%$ \\
\hline 5. & \multirow{2}{*}{$0 \%$} & $13,9 \%$ & $13,9 \%$ & $7,9 \%$ & $18,8 \%$ & $33,7 \%$ \\
\cline { 1 - 6 } 6. & & $\mathbf{7 4 , 3} \%$ & $0 \%$ & $6,9 \%$ & $1 \%$ & $5,9 \%$ \\
\hline
\end{tabular}

2. táblázat: A különböző szerepek százalékos megjelenése az APA feladatainak megítélésében

A fenti táblázatból az látszik, hogy a kitöltő édesapák 81,2\%-a az Anyagi biztonság megteremtését az első helyen jelölte meg, míg a Gyermekgondozás a legnagyobb értéket a második helyen, 35,6\%-kal kapta. A Gyermeknevelés a legnagyobb értéket, 44,6\%-kal a harmadik helyen érte el. A Házastárssal töltött idő és a Háztartás körüli teendők közel azonos értékkel szerepelnek a negyedik helyen. A Háztartásvezetés a hatodik helyen érte el a legmagasabb értéket, ezek szerint 74,3\%-kal a legkevésbé fontos apai tevékenységnek tartják a kutatásban részt vevő édesapák.

Vizsgáltuk továbbá, hogy az édesapák milyen játéktevékenységeket végeznek gyermekeikkel közösen. Hipotéziseink alapján arra voltunk kíváncsiak, hogy szívesebben játszanak-e fizikai játékokat, mint szellemi vagy szerepjátékokat. Itt külön vizsgáltuk a birkózás-feldobálást, számítógépes játékokat, csiklandozást, társasjátékokat, kártyajátékokat, szerepjátékokat, építőjátékokat és a nemek szerinti játékokat. A kitöltők feladata itt az volt, hogy a különböző játéktevékenységek között különbséget tegyenek aszerint, hogy soha, ritkán, alkalmanként, naponta, vagy naponta többször végzik-e gyermekeikkel közösen.

A kutatásból kiderül, hogy a kitöltők összesen 59,4 \%-a naponta, vagy naponta többször játszik gyermekével birkózósat, feldobálóst, továbbá az is látszik, hogy kifejezetten kevesen, mindössze 16,8 százaléknyian vannak azok, akik soha, vagy ritkán végzik a fent említett tevékenységeket. A csiklandozást azért vettük külön tevékenységként, mert úgy gondoltuk, hogy a birkózáshoz és a feldobáláshoz képest kevésbé erős indulati töltetü, kevésbé heves tevékenység, és sokkal intimebb is. Itt az derült ki, hogy a kitöltők 41,6 \%-a naponta többször teremt közvetlen testi kapcsolatot csiklandozással, illetve további 37,6 \% naponta. A lenti táblázatból is könnyen megállapítható tehát, hogy a leggyakoribb napi szinten előforduló játéktevékenység az édesapák és gyermekeik között a csiklandozás, birkózás valamint az építőjátékok, mivel azt szintén gyakran, leginkább naponta, vagy alkalmanként játszanak gyermekeikkel.

Számítógépes játékok, kártyajátékok és társasjátékok esetében a „soha” és a „ritkán” válaszokat látjuk a leggyakoribbnak, melyre magyarázatul szolgálhat a gyermekek alacsony átlagéletkora is. A nemek szerinti játékok terén nagyon megoszlottak a válaszok, kifejezetten érdekes, hogy a két legnagyobb érték a „soha” és a „naponta” oszlopban jelent meg $21,8 \%$ és $24,8 \%$-kal. 
Az apa szerepe a kisgyermek életében

\begin{tabular}{|l|c|c|c|c|c|}
\hline & Soha & Ritkán & Alkalmanként & Naponta & $\begin{array}{c}\text { Naponta } \\
\text { többször }\end{array}$ \\
\hline $\begin{array}{l}\text { Birkózás, } \\
\text { Feldobálás }\end{array}$ & $9,9 \%$ & $6,9 \%$ & $23,8 \%$ & $\mathbf{2 9 , 7} \%$ & $\mathbf{2 9 , 7} \%$ \\
\hline $\begin{array}{l}\text { Számítógépes } \\
\text { játékok }\end{array}$ & $\mathbf{6 7 , 3} \%$ & $14,9 \%$ & $13,9 \%$ & $4 \%$ & $0 \%$ \\
\hline Csiklandozás & $0 \%$ & $4 \%$ & $14,9 \%$ & $\mathbf{3 7 , 6} \%$ & $\mathbf{4 1 , 6} \%$ \\
\hline Társasjáték & $26,7 \%$ & $\mathbf{3 6 , 6} \%$ & $25,7 \%$ & $10,9 \%$ & $0 \%$ \\
\hline Kártyajáték & $\mathbf{3 8 , 6} \%$ & $29,7 \%$ & $27,7 \%$ & $\mathbf{4} \%$ & $0 \%$ \\
\hline Szerepjátékok & $21,8 \%$ & $17,8 \%$ & $21,8 \%$ & $\mathbf{3 0 , 7} \%$ & $7,9 \%$ \\
\hline Építő játékok & $5,9 \%$ & $3 \%$ & $\mathbf{3 6 , 6} \%$ & $\mathbf{4 1 , 6} \%$ & $12,9 \%$ \\
\hline $\begin{array}{l}\text { Nemek szerinti } \\
\text { játékok }\end{array}$ & $\mathbf{2 1 , 8} \%$ & $17,8 \%$ & $18,8 \%$ & $\mathbf{2 4 , 8} \%$ & $16,8 \%$ \\
\hline
\end{tabular}

3. táblázat: Különböző játéktevékenységek gyakorisága a kitöltők körében

Vizsgáltuk továbbá, hogy az édesapák számára mennyire fontos, hogy gyermekük, kiváltképpen, ha az azonos nemü, hasonló érdeklődési körrel rendelkezzen, mint ök. Ehhez összehasonlítottuk, hogy a vonatkozó kérdésekre adott válaszok közül hány fiú gyermeket nevelö édesapa válaszolta azt, hogy számára nagyon fontos hogy gyermekével megegyező legyen az érdeklődési körük, majd ebből százalékosan számoltuk ki az arányokat, mivel ahogy azt már korábban említettük, 20\%-kal több lány gyermekes apa töltötte ki a kérdőívet, mint fiú gyermeket nevelö.

\begin{tabular}{|l|c|c|c|}
\hline & $\begin{array}{c}\text { Lánygyermeket } \\
\text { nevelő apák } \\
(\mathrm{N}=61)\end{array}$ & $\begin{array}{c}\text { Fiúgyermeket } \\
\text { nevelő apák } \\
(\mathrm{N}=40)\end{array}$ & Összesen \\
\hline $\begin{array}{l}\text { Nagyon fontos, } \\
\text { vagy fontos }\end{array}$ & $\begin{array}{c}34,4 \% \\
(21 \mathrm{fö})\end{array}$ & $\begin{array}{c}\mathbf{5 0} \% \\
(20 \text { fö })\end{array}$ & 41 fö \\
\hline $\begin{array}{l}\text { Nem különösebben } \\
\text { fontos }\end{array}$ & $\begin{array}{c}\mathbf{5 4 , 1} \% \\
(33 \text { fö })\end{array}$ & $\begin{array}{c}47,5 \% \\
(19 \text { fö })\end{array}$ & 52 fö \\
\hline Egyáltalán nem & $\begin{array}{c}11,5 \% \\
(7 \text { fö })\end{array}$ & $\begin{array}{c}2,5 \% \\
(1 \text { fő })\end{array}$ & 8 fö \\
\hline
\end{tabular}

4. táblázat: Azonos érdeklődési kör fontossága az apáknak gyermekeikkel

A táblázat alapján megállapítható, hogy bár az apák alapvetően közömbösek gyermekük hasonló érdeklődési köre kapcsán, a fiú gyermeket nevelő apák számára inkább fontos ez a tény, mint a lány gyermeket nevelő apák számára. A lányok esetében nagyobb az aránya azoknak, akiknek egyáltalán nem fontos, hogy gyermekével azonos érdeklődési körrel rendelkezzen, míg fiúk esetében, erre mindössze egyetlen kitöltő válaszolt így.

\section{Összefoglalás}

Kutatásunkban szerettük volna alátámasztani a szakirodalmi háttér alapján megfogalmazódott hipotéziseket, melyek segítettek számunkra jobban megérteni az apa-gyermek kapcsolat működését, valamint az apa-gyermek közös tevékenységek jellegzetességeit 
napjainkban, leginkább az apák részéröl. Kifejezetten érdekes volt látni, hogy milyen különbözőképpen gondolkodnak apai és anyai szerepekről, játékokról és együtt töltött időröl a kitöltésben részt vevő édesapák. Úgy gondoljuk, hogy bár manapság a kutatások alapján egyre inkább a „modern apák” idejét éljük (Simón, Sánchez és Elizalde, 2005), akik ott vannak a szülőszobán, előszeretettel pelenkázzák, etetik gyermeküket, és gyakran együtt játszanak a kicsivel, azért még továbbra is jelen van az a hagyományos szemlélet és nemi szerepelvárás, mely a gyermek érzelmi nevelését és gondozási tevékenységeinek ellátását az édesanyák feladatának tartja. Véleményünk szerint azonban nem feltétlenül okoz problémát, ha az apa kis mértékben megmarad a hagyományos értelemben vett „tanító és fegyelmező" szerepben addig, amíg az a gyermeke érdekeit, egészséges fejlődését és alakuló énhatárainak megszilárdulását segíti elő, és a gyermekkel együtt töltött idő ezáltal jobbá, minőségivé válhat, valamint mindkét nemű szülő szerepreprezentációját integrálhatja.

\section{Kitekintés}

A vizsgálatunkat a későbbiekben az apa szerepének édesanyák általi megítélésével, illetve a nemi szerepekröl alkotott női attitűdök feltárásával folytatjuk. Célunk a bölcsődét igénybe vevő és nem igénybe vevő szülők közötti ilyen irányú különbségek meglétének vizsgálata, lehetőség szerint a jelenleginél nagyobb mintán. Célunk továbbá a játéktevékenységek hatásának vizsgálata a szülők erről alkotott nézeteinek tükrében, és az ezzel töltött valós időtartam és intenzitás előbbiekkel való kapcsolatainak feltárása. Terveink között szerepel a gyermekgondozás és a gyermeknevelés fogalmi különbségeinek és ezek viselkedésre gyakorolt hatásának vizsgálata az édesapák körében.

\section{Irodalom}

Ariés, P. (1987): Gyermek, család, halál, Gondolat Könyvkiadó, Budapest.

Benedek Szidónia Anna (2014): Az apa szerepe a kisgyermek életében. Szakdolgozat, Eszterházy Károly Főiskola - Tanárképzési és Tudástechnológiai Kar, Eger.

Bimbóné Mészáros Jutka (é.n.): Napvirág, Kisgyermeket nevelők észak-magyarországi regionális kiadványa. Böl-CSIBE Alapítvány, Eger.

Bowlby, J. (2009): A biztos bázis - A kötődés-elmélet klinikai alkalmazásai, Animula Kiadó, Budapest.

French, V. (1998): A gyermek hatásának története. In: Vajda Zsuzsanna és Pukánszky Béla (szerk.): A gyermekkor története, Eötvös Kiadó, Budapest, 42-67.

Lorentzen, J. (2012): Az apaszerep története Norvégiában 1850-2012. Pont Kiadó, Budapest.

Pukánszky Béla és Németh András (2001): Neveléstörténet. URL: http://magyar-irodalom.elte.hu/nevelestortenet/index.html (letöltve: 2014.03.09.)

Ranschburg Jenő (2003): Az én és a másik - A személyiség és a társas kapcsolatok fejlődése óvodáskorban, Okker Kiadó, Budapest.

Ranschburg Jenő (2009): Szülők könyve - A fogantatástól az iskolakezdésig, Saxum Kiadó KFT, Budapest.

Sears, W. (2006): Éjszakai Gondoskodás, Sanoma Budapest Kiadó Zrt., Budapest.

Simón, M., Sánchez, M. és Elizalde, Q. (2005): Simogató babamasszázs. Alexandra Kiadó, Pécs.

Spock, B. és Parker, S. J. (2010): Spock doktor csecsemö- és gyermekgondozása. Kézikönyv szülöknek a gyermekek helyes gondozásáról, születéstöl a kamaszkorig. Medicina Könyvkiadó, Budapest.

Sullivan R. (2003): Focus on Fathering. ACER Press, Melbourne.

Tomka Béla (2000): Családfejlődés a 20. századi Magyarországon és Nyugat Európában: Konvergencia vagy divergencia? Osiris Kiadó, Budapest. 
Vajda Zsuzsanna (1999): A gyermek pszichológiai fejlődése, Helikon kiadó, Budapest.

Vukovics György (2006): Az elvált apák helyzetének néhány aspektusa. In: Kolosi Tamás, Tóth István György és Vukovich György (szerk.) Társadalmi riport 2006, TÁRKI, Budapest, 267-283.

URL: http://www.tarsadalomkutatas.hu/kkk.php?TPUBL-A-699/publikaciok/tpubl_a_699.pdf (letöltve): 2014.03.12. 


\section{Melléklet}

\section{Kérdőív}

\section{ÁLTALÁNOS KÉRDÉSEK}

1. Az Ön életkora?

2. Az Ön lakhelye?
a. Főváros
b. Megyei jogú város
c. Város
d. Település, község

3. Az Ön legmagasabb iskolai végzettsége?
a. Kevesebb, mint 8 általános
b. 8 általános
c. Szakmunkásképzö, Szakközépiskola, Szakiskola, Technikum
d. Gimnázium (érettségi)
e. Főiskola/egyetem

4. Az Ön családi állapota?
a. Házasságban élek, gyermeke(i)m van(nak)
b. Házasság nélkül, párkapcsolatban élek, gyermeke(i)m van(nak)
c. Elvált vagyok, gyermeke(i)m felügyeleti jogával
d. Elvált vagyok, gyermeke(i)m felügyeleti joga nélkül

5. Mi az Ön legföbb bevételi forrása?
a. Állandó munka
b. Alkalmi munka
c. Segély, szociális támogatás, családi támogatás
d. Bankhitel
e. Egyéb, éspedig:

6. Milyennek ítéli családja anyagi helyzetét?
a. Átlagnál sokkal jobb
b. Átlagnál valamivel jobb
c. Átlagos
d. Átlagnál valamivel szegényebb
e. Átlagnál sokkal szegényebb

7. Hány órát tölt egy átlagos héten az alábbi tevékenységekkel?
a. TV-nézés:
b. Infokommunikációs eszközök (táblagép, mobiltelefon, laptop, számító- gép):
c. Sport:
d. Színház/mozi:
e. Szórakozás barátokkal/kocsma:
f. Házastárssal töltött idő kettesben:
g. Gyermekkel töltött idő:
h. Családdal töltött idő - kirándulás, közös játék:
i. Munka: 
8. Rangsorolja az alábbi fogalmakat 1-től 7-ig, fontosságuk szerint! (1=legfontosabb; 7=legkevésbé fontos)

\begin{tabular}{|c|c|}
\hline & Egészség \\
\hline & Vallás, Spiritualitás \\
\hline & Szórakozás \\
\hline & Barátok \\
\hline & Karrier, Pénz \\
\hline & Párkapcsolat \\
\hline & Család \\
\hline
\end{tabular}

Állítsa sorrendbe 1-től 6-ig, saját véleménye szerint az Anya feladatait! ( 1 =legfontosabb; 6 =legkevésbé fontos)

\begin{tabular}{|c|c|}
\hline & Családfenntartás, anyagi biztonság megteremtése \\
\hline & Háztartásvezetés (fözés, mosás, vasalás stb.) \\
\hline & Gyermeknevelés (vigasztalás, ringatás, meseolvasás stb.) \\
\hline & Házastárssal töltött idő \\
\hline & $\begin{array}{c}\text { Gyermekgondozás (etetés, pelenkázás, altatás, fürdetés stb.) } \\
\text { Háztartás körüli teendők (fünyírás, villanykörtecsere, házimunká- } \\
\text { ban való segítés) }\end{array}$ \\
\hline
\end{tabular}

9. Állítsa sorrendbe 1-től 6-ig, saját véleménye szerint az Apa feladatait! (1=legfontosabb; $6=$ =legkevésbé fontos)

\begin{tabular}{|c|c|}
\hline & Házastárssal töltött idő \\
\hline & $\begin{array}{c}\text { Háztartás körüli teendök (fünyírás, villanykörtecsere, házimunká- } \\
\text { ban való segítés) }\end{array}$ \\
\hline & Háztartásvezetés (főzés, mosás, vasalás stb.) \\
\hline & Gyermekgondozás (etetés, pelenkázás, altatás, fürdetés) \\
\hline & Családfenntartás, anyagi biztonság megteremtése \\
\hline & Gyermeknevelés (vigasztalás, ringatás, meseolvasás stb.) \\
\hline
\end{tabular}




\section{GYERMEKRE VONATKOZÓ KÉRDÉSEK}

Az itt leírt kérdéseket, több gyermek esetén, csak egy gyermekkel kapcsolatban töltse ki. Arra a gyermekre vonatkozóan, aki korban 0-3 év közé (maximum 5 éves) esik.

1. Hány gyermeke van jelenleg?
a. 1
b. 2
c. 3
d. 4
e. 4-nél több

2. Mennyi idős a gyermeke?(akiről a kérdőívet tölti)

3. Gyermeke hányadik gyermekként született?(akiről a kérdőívet tölti) _

4. Milyen nemü a gyermeke?
a. lány
b. fiú

5. Jár(t) gyermeke bölcsődébe?
a. igen
a. nem

6. (Ha IGEN) Ki szoktatta be a gyermeket a bölcsődébe? (TÖBB válasz is megjelölhető)
a. anya
b. apa
c. nagyszülő
d. más, mégpedig:

7. Volt Ön otthon gyermekével Gyes-en/Gyed-en?
a. igen
b. nem.

8. Ott volt Ön a szülőszobán gyermeke születésénél?
a. igen
b. nem

i. Ha NEM, mi volt ennek az oka:

9. Hogyan kísérte figyelemmel gyermeke fejlődését az első hónapokban? (TÖBB válasz megjelölése is lehetséges)
a. ott voltam, amikor elöször megfordult
b. ott voltam, amikor először mászott
c. ott voltam, amikor először felállt
d. ott voltam, amikor először elindult
e. ott voltam, amikor először megszólalt
f. nem voltam ott személyesen ezeknél a pillanatoknál 
10. Ön milyen gyakran játssza az alábbiakat gyermekével? (Tegyen $\mathbf{X}$-et a megfelelő oszlopba)

\begin{tabular}{|c|c|c|c|c|c|}
\hline & SOHA & RITKÁN & $\begin{array}{l}\text { ALKALMAN- } \\
\text { KÉNT }\end{array}$ & NAPONTA & $\begin{array}{l}\text { NAPONTA } \\
\text { TÖBBSZÖR }\end{array}$ \\
\hline $\begin{array}{l}\text { Birkózás, } \\
\text { Feldobálás }\end{array}$ & & & & & \\
\hline $\begin{array}{l}\text { Számítógé- } \\
\text { pes játékok, } \\
\text { PlayStation }\end{array}$ & & & & & \\
\hline Csiklandozás & & & & & \\
\hline Társasjáték & & & & & \\
\hline Kártyajáték & & & & & \\
\hline $\begin{array}{l}\text { Szerepjátékok } \\
\text { (rendőrös, or- } \\
\text { vosos, boltos, } \\
\text { apás-anyás stb.) }\end{array}$ & & & & & \\
\hline $\begin{array}{l}\text { Építő játékok } \\
\text { (Lego, Duplo, } \\
\text { fakocka stb.) }\end{array}$ & & & & & \\
\hline $\begin{array}{l}\text { Nemek szerinti } \\
\text { játékok } \\
\text { (babázás/autó- } \\
\text { zás) }\end{array}$ & & & & & \\
\hline $\begin{array}{l}\text { Egyéb, éspe- } \\
\text { dig: }\end{array}$ & & & & & \\
\hline
\end{tabular}

11. Milyen NEM játéktevékenységet végez gyermekével közösen?(TÖBB válasz is lehetséges)

a. Tv-nézés, amikor Ön választ programot (húzza alá a megfelelő(ke)t)

i. sport

ii. híradó

iii. természetfilm

iv. film

b. TV-nézés, amikor a gyermek választ programot

c. Segíthet Önnek a barkácsolásban és a ház körüli munkákban 
d. Sporttevékenység

e. Házimunka (fözés, takarítás stb.)

f. Kirándulás a természetben

g. Színház/Mozi/Koncert

h. Egyéb, éspedig:

12. Mennyire fontos Önnek, hogy gyermeke azonos érdeklödési körrel rendelkezzen?
a. nagyon fontos
b. fontos
c. nem különösebben fontos
d. egyáltalán nem fontos

13. Az alábbi tulajdonságok alapján mennyire hasonlítanak egymásra gyermekével? (Kérem, tegyen $\mathbf{X}$-et a megfelelő oszlopba)

\begin{tabular}{|l|l|l|l|l|l|}
\hline & $\begin{array}{c}\text { Teljesen rám } \\
\text { hasonlít }\end{array}$ & $\begin{array}{c}\text { Inkább rám } \\
\text { hasonlít }\end{array}$ & $\begin{array}{c}\text { Nem tudom } \\
\text { eldönteni }\end{array}$ & $\begin{array}{c}\text { Inkább az } \\
\text { anyjára ha- } \\
\text { sonlít }\end{array}$ & $\begin{array}{c}\text { Teljesen az } \\
\text { anyjára ha- } \\
\text { sonlít }\end{array}$ \\
\hline Nyugodtság & & & & & \\
\hline Érzékenység & & & & & \\
\hline Kapcsolatteremtés & & & & & \\
\hline Temperamentum & & & & & \\
\hline Magabiztosság & & & & & \\
\hline Fél az ismeretlentöl & & & & & \\
\hline
\end{tabular}

14. Mi jellemző gyermekére, amikor idegen helyen (vagy akár bölcsődében) elválnak egymástól?
a. Sír, sokáig vigasztalhatatlan
b. Kicsit sír, de hamar vigasztalódik
c. Elszomorodik, de nem sír, könnyen vigasztalható
d. Különösebben nem reagál a távozásomra, hamar elfoglalja/feltalálja magát
e. Ellentmondásosan viselkedik (pl.: egyik pillanatban megölel, majd ellök magától)

15. Mi jellemző gyermekére, amikor bizonyos idő után újra találkoznak?

a. Aktívan üdvözöl, láthatóan nagyon örül

b. Eltávolodik, szándékosan nem figyel, „sértődött”

c. Zaklatottnak látszik, dühös, esetleg sír

d. Ellentmondásosan viselkedik (pl.: egyik pillanatban megölel, majd ellök magától)

16. Van olyan tevékenység, amit a gyermek szívesebben végez az apával, mint az anyával? Ha igen, mi(k) az(ok)? 